\title{
Transposon Insertion Phenomenon during Cloning of a Partial Fragment Derived from Metagenomic DNA Isolated from Deep-Sea Water and Sediment of Kawio Island, North Sulawesi
}

\section{Fenomena Insersi Transposon pada Proses Kloning Fragmen Parsial dari DNA Metagenom yang Diisolasi dari Air dan Sedimen Laut-Dalam Perairan Pulau Kawio, Sulawesi Utara}

\author{
Mochamad Untung Kurnia Agung ${ }^{1 *}$ and Maelita Ramdani Moeis ${ }^{2}$ \\ ${ }^{1}$ Department of Marine Science, Faculty of Fisheries and Marine Sciences, University of Padjadjaran (UNPAD), Sumedang \\ ${ }^{2}$ School of Life Science and Technology, Bandung Institute of Technology (ITB) \\ *Correspondence Author: mochamad.untung@gmail.com \\ Article history: \\ Received: 3 April 2013; Revised: 18 November 2013; Accepted: 19 November 2013
}

\begin{abstract}
Transposon is well-known as mobile element found abundant both in prokaryote and eukaryote genomes. In bacteria, transposon (famous name of a transposable DNA) could jump from chromosome to plasmid and its contrary. One type of transposons in bacteria known as insertion sequence (IS), it does not contain any additional genes except a gene encoding transposase, an enzyme that correlated to transponsition activities. The finding of transposon insertion unfortunately found during cloning of a fragment derived from deep-sea metagenomic DNA in this research. In the initial, this research was aimed to clone and characterize the á-amylase encoded gene derived from metagenomic DNA isolated from deep-sea water and sediment of Kawio Island, North Sulawesi. Metagenomic DNA has been isolated from deep-sea water and sediment and by using Whole Genome Amplification (WGA) technique, the DNA it could be increased in quantities to $146,31 \mathrm{ng}$ for each $1 \mathrm{ng}$ of metagenomic DNA. A fragment of $\sim 1000 \mathrm{bp}$ in length was obtained by using touchdown PCR method. The presence of a transposon in this DNA fragment is proposed as a hypothesis for losing $\sim 700$ bp leaving just 310 bp cloned sequence. Analysis of sequencing result showed a highest similarity between this $310 \mathrm{bp}$ partial fragment with a replication protein (Rep) encoded gene from Pseudomonas putida (Query Coverage: 88\%; Max. Identity: 80\%, Positive: $86 \%)$ and this protein is known to be involved in plasmid replication where transposase encoding genes known usually presence together with this gene (Rep gene) in a bacterial plasmid.
\end{abstract}

Keywords: transposon, metagenomic, partial fragment, cloning, deep-sea

\section{ABSTRAK}

Transposon yang dikenal sebagai mobile element ditemukan melimpah pada genom prokariot maupun eukariot. Pada bakteri, transposon dapat berpindah dari kromosom ke dalam plasmid dan atau sebaliknya. Salah satu jenis transposon yang ditemukan pada bakteri yang dikenal sebagai insertion sequence (IS), diketahui tidak mengkode gen tambahan lain kecuali gen pengkode transposase, yaitu enzim yang berperan pada aktivitas transposisi dari suatu transposon. Penemuan fenomena aktivitas insersi (transposisi) dari suatu transposon secara tidak sengaja ditemukan pada saat proses kloning suatu fragmen parsial yang berasal dari DNA metagenom laut-dalam pada penelitian ini. Pada mulanya, penelitian ini bertujuan untuk mengklon dan mengkarakterisasi gen pengkode a-amilase yang ditapis dari DNA metagenom yang diisolasi dari air dan sedimen laut-dalam perairan Pulau Kawio, Sulawesi Utara. DNA metagenom berhasil diisolasi dari sampel air dan sedimen laut-dalam dan dengan menggunakan teknik Whole Genome Amplification (WGA) berhasil ditingkatkan kuantitasnya hingga mencapai 146,31 ng untuk setiap $1 \mathrm{ng}$ DNA metagenom. Suatu fragmen parsial berukuran $\sim 1000 \mathrm{pb}$ berhasil diisolasi dengan menggunakan metode touchdown PCR. Fenomena kehadiran transposon dalam fragmen parsial tersebut terungkap pada saat proses kloning di mana terjadi perubahan ukuran fragmen menjadi hanya $310 \mathrm{pb}$ pada akhir tahapan kloning. Analisis hasil sekuensing menunjukkan kemiripan tertinggi fragmen tersebut dengan gen pengkode replication protein (Rep) dari bakteri Pseudomonas putida (Query Coverage: $88 \%$; Max. Identity: $80 \%$, Positive: $86 \%$ ) dan protein ini diketahui terlibat pada proses replikasi plasmid di mana gen pengkode transposase juga diketahui hadir bersama gen ini (gen Rep) pada plasmid suatu bakteri.

Kata Kunci: transposon, metagenomik, fragmen parsial, kloning, laut dalam

Permalink/DOI: http://dx.doi.org/10.15578/squalen.v8i3.84 


\section{Introduction}

The marine environment is a landscape that has unique physical, chemical, and biological characteristics. From the point of the study of biology, deep-sea environments, including hydrothermal vent ecosystems, has its own uniqueness. Unique characteristics of enzymes and secondary metabolites produced by marine microorganisms-in to benefit the search of new enzymes (novel enzymes) that are useful for industrial purposes, food, and raw materials of drugs (Steele et al., 2005). One of the interesting enzymes is $\alpha$-amylase, an enzyme that has wide scale use in biotechnology-based industries, especially in starch-based food industries to convert polysaccharide into simple sugars such as glucose, maltose, dextrin, and other oligosaccharides (Rahmani et al., 2011).

Metagenomic is an approach in genomic analysis to gain insight into the genetics of entire microbial communities without cultivation process of certain microbial species (Schloss \& Handelsman, 2003). Since it is known that only about $1 \%$ of microbes that can be cultured (culturable) and the remaining, more than $98 \%$ are microbial communities that cannot be cultured (unculturable) (Sharma, 2005).then metagenomic offer another approach that can access a large number of microbes that cannot be cultured (Handelsman et al., 2007). The exploration of marine microbial community through metagenomic approach initiated in 1985, when Pace and his team conducted a total DNA extraction from marine plankton to obtain genetic information from its ligated fragments (Lane et al., 1985; Vakhlu et al., 2008).

Transposable elements are DNA sequences that are capable of mediating their own movement (transposition) to new locations within the genome they inhabit. In bacteria, transposable elements can generally be assigned to one of two major types, "Insertion Sequences (IS)" and "Composite Transposons". In practice, composite transposons are typically referred to simply as "transposons". Insertion sequences (IS's) are transposable elements whose only have genes that are directly related to promotion and regulation of their transposition, typically the gene is called as a transposase gene. IS elements are between $700-2,000$ bp in length and are characterized by short, terminal, inverted repeat sequences with the ORF or ORF's in between. They are normal constituents of many bacterial chromosomes and plasmids. Composite transposons generally consist of two copies of the same IS element flanking variable amounts of other DNA sequences coding for one or several genes with diverse functions. The best known transposons are those which were discovered as parts of antibiotic resistance plasmids (Aziz et al., 2010).
Several enzymes have been successfully explored from deep-sea environment through metagenomic approach include: xylanase (Collins et al., 2002), protease (Zeng et al., 2003), chitinase (Hobel et al., 2005), esterase (Ferrer et al., 2005; Park et al., 2007), amylase (Mathur et al., 2006), alkaline hydroxylase (Xu et al., 2008), and lipase (Jeon et al., 2009). In the initial, this research was aimed to clone and characterize the gene encoding $\alpha$-amylase from metagenom DNA derived from sea-water and sediment in the waters of West Kawio island, North Sulawesi.

\section{Materials and Methods}

\subsection{Deep-sea Water and Sediment}

The deep-sea water and sediment that used as main samples of this research were obtained from 1500-3000 m depth bellow the sea surface of West Kawio Island, Sangihe Talaud archipelago, North Sulawesi where the point of sampling station located at $5^{\circ} 72203 \mathrm{~N}$ dan $127^{\circ} 14203 \mathrm{E}$. Generally, physical and chemical condition of sampling area were described as high pressure with 317 atm; the temperature surrounding the vent was measured in range of $35-80^{\circ} \mathrm{C} ; \mathrm{pH}$ in range of 2,8-6,5; and salinity in range of 35-40 ppt. This samples were collected (with permission) by The INDEX-SATAL ocean expedition that was conducted on July-August 2010 as international collaboration between the government of Indonesia and The United State of America.

\subsection{Metagenomic DNA isolation and Whole Genome Amplification (WGA)}

Metagenomic DNA was isolated from $300 \mathrm{ml}$ of deep-sea water using Rapid Water ${ }^{\mathrm{TM}} \mathrm{Kit}\left(\mathrm{MOBIO}^{\circledR}\right)$ and its quantities were increased through Whole Genome Amplification (WGA), a method based on Multiple Displacement Amplification (MDA), using Repli-G Mini $\mathrm{Kit}^{\mathrm{TM}}\left(\right.$ QIAGEN $\left.^{\circledR}\right)$.

\subsection{Screening of $\alpha$-Amylase Encoding Gene}

Screening of $\alpha$-amylase encoding gene was done through touch-down PCR method using PCR $2 \mathrm{G}$ Robust Hotstart ${ }^{\mathrm{TM}}\left(\mathrm{KAPA}^{\circledR}\right)$. The PCR component consist of Buffer A (1X), $\mathrm{MgCl}_{2}(0,5 \mathrm{mM})$, dNTP mix $(0,2 \mathrm{mM})$, Primers $(0,1 \mathrm{iM})$, KAPA $2 \mathrm{G}$ Robust Polymerase ( $5 \mathrm{u})$, DNA template (100 $\mathrm{ng})$, and Nuclease free water (up to 10 i L final volume). The PCR primers were designed from a consensus of 17 $\alpha$-amylase encoding genes databases of several marine bacterias. These primers sequences are described as 5'-CATATGCGATTT GAAAGG CGTCA CGGCG-3' (forward primer) and 5'-GGAT 
CCACATAGACGCTGACAATCGCCGCA-3' (reverse primer). The PCR was run on $47-57^{\circ} \mathrm{C}$ annealing temperature range with products were estimated 1281 bp in length.

\subsection{Cloning of $\alpha$-Amylase Encoding Gene}

The $\alpha$-amylase encoding gene was cloned using PGEM ${ }^{\mathrm{TM}}-\mathrm{T}$ Easy cloning vector $\left(\mathrm{PROMEGA}^{\circledR}\right)$. The cloning was done within $E$. coli DH5 $\alpha$ competent as the host cell, that has been optimized into $1,96 \times 10^{6}$ cfu $\mu \mathrm{g}$ of plasmid DNA as its transformation efficiency (Tu et al., 2005; Roychoudhury et al., 2009).

\subsection{Sequencing Analysis}

Sequencing service was done by Macrogen, Inc. (Korea). EXPASY Translate Tool TM (http://web.expasy. org/translate/) was used to translate the consensus of nucleotide sequences into amino acid sequences and also to predict open reading frame (ORF) within the sequences. Further bioinformatics analysis of the chosen ORF were done to characterize conserved domains, active sites, and protein motifs of the sequence.

\section{Results and Discussion}

\subsection{Metagenomic DNA Isolation and WGA}

Isolation was successfully obtained $\sim 21 \mathrm{~kb}$ of metagenomic DNA in length as $104 \mathrm{ng}$ (in $100 \mu \mathrm{l}$ ) in quantities. Through WGA, it could be increased in quantities to $146,31 \mathrm{ng}$ for each $1 \mathrm{ng}$ of metagenomic DNA (Figure 1).

WGA was done using multiple displacement amplification (MDA) mechanism, utilized the unique activities of phi29 DNA polymerase and degenerate hexamer primers within isothermal temperature at $30^{\circ} \mathrm{C}$ (Dean et al., 2002). Phi29 DNA polymerase is from Õ29 bacteriophage and it was proved able to add

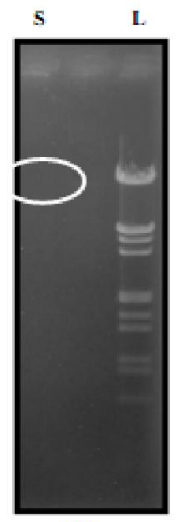

(A)
70.000 of nucleotide (dNTPs) for every single primers bind, and it made MDA could synthesis long product of amplification, up to $200 \mathrm{~kb}$. It was important for genomic library construction, with less of error proofed when compared with conventional PCR method (Lasken et al., 2003) (Paez et al., 2004).

\subsection{Screening of $\alpha$-Amylase Encoding Gene}

Screening of $\alpha$-amylase encoding gene was done through touchdown PCR method on $47-57^{\circ} \mathrm{C}$ annealing temperature range. As the result, there were multiple bands appeared in gel electrophoresis (Figure 2). The single band at $\sim 1000 \mathrm{bp}$ in length seemed thicker than others. This band then be purified to be cloned.

\subsection{Cloning of $\alpha$-Amylase Encoding Gene}

DNA fragment of $\sim 1000$ bp that has been purified from gel electrophoresis then be ligated to $P G E M^{T M}-T$ Easy cloning vector $\left(P R O M E G A^{\circledR}\right)$. Competent cells of $E$. coli $\mathrm{DH} 5 \alpha$ then be transformed by the ligated plasmids. In this research we have done for four times of transformation. For each transformation, plasmids of positive clones then be isolated. At the first transformation, there were 7 positive clones that successfully being isolated its plasmids. The confirmation of uncut plasmid within these clones has been done using electrophoresis (Figure 3 ). The observation of uncut plasmids migration on gel electrophoresis showed that the seven positive clone plasmids have similar migration distance with circular uncut of PGEM ${ }^{\mathrm{TM}}-\mathrm{T}$ Easy (no insert DNA). It showed that the insert DNA of the positive clone plasmids have just short in length. The plasmids might that migrate over the PGEM ${ }^{\mathrm{TM}}-\mathrm{T}$ Easy were guessed containing an insert DNA. Confirmation of these insert was done using PCR method (Figure 4).

Figure 4 told us that all of 5 positive clone plasmids that have been confirmed using first early primers resulted a $\sim 300$ bp band product as insert, not $\sim 1000$ bp as initial insert during ligation.

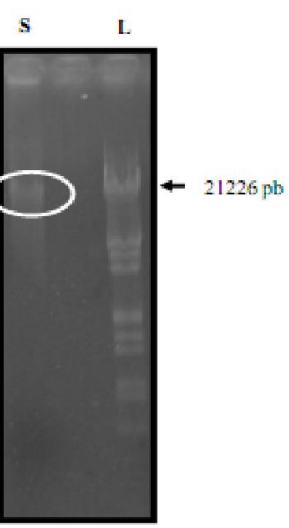

(B)

Figure 1. Electroferogram (A) Result of Isolation of Metagenomic DNA, (B) Result of Whole Genome Amplification (WGA); L : DNA $\lambda$ Hind III + EcoR1 Ladder (FERMENTAS ${ }^{\circledR}$ ); S : Sample. 


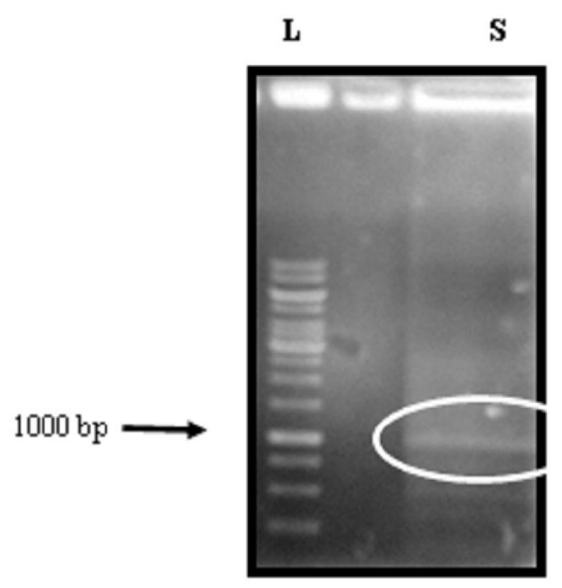

Figure 2. Result of Touchdown PCR; L: 1 kb DNA Ladder ${ }^{\mathrm{TM}}$ (FERMENTAS ${ }^{\circledR}$ ); S: Sample.

PGEM-T L RSII RSIII RSI?a RSI2C RSIIf RSIAb RSIAd I

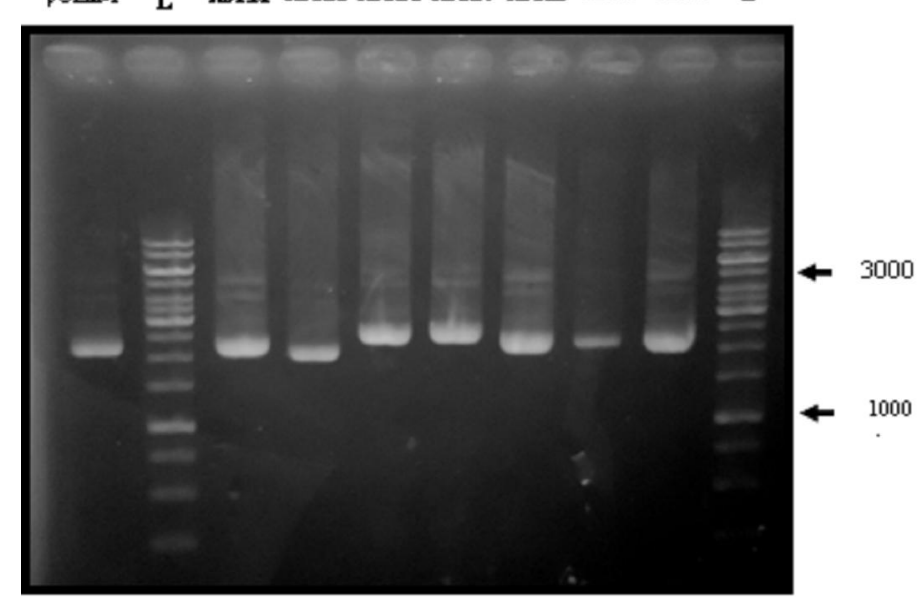

Figure 3. Electroferogram of uncut plasmid migration of isolated positive clone plasmids at $1^{\text {st }}$ transformation; L: 1 kb DNA Ladder ${ }^{\text {TM }}$ (FERMENTAS $\left.{ }^{\circledR}\right) ;$ RSI.[1,2,3,4].[a,b,c, .....etc] : Plasmids of Positive Clones

\section{RSL1a RSL2a RSL2c RSL4h RSL4d}

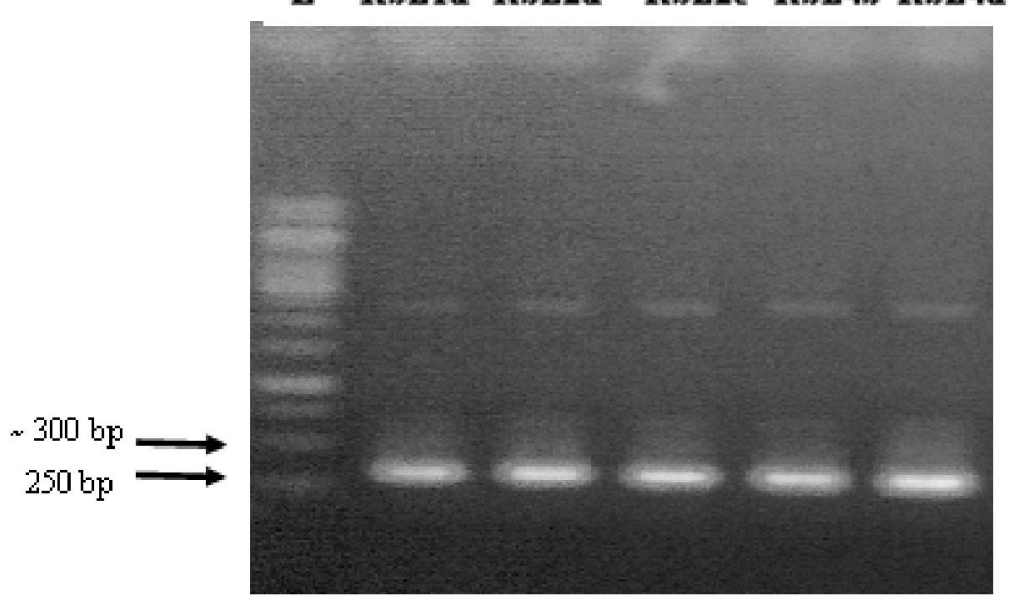

Figure 4. Electroferogram of Insert DNA confirmation based on PCR method L: $1 \mathrm{~kb}$ DNA Ladder ${ }^{\mathrm{TM}}$ $\left(\right.$ FERMENTAS $\left.^{\circledR}\right)$ RSI.[1a; 2a; 2c; 4b; 4d] : Plasmids of positive clones 


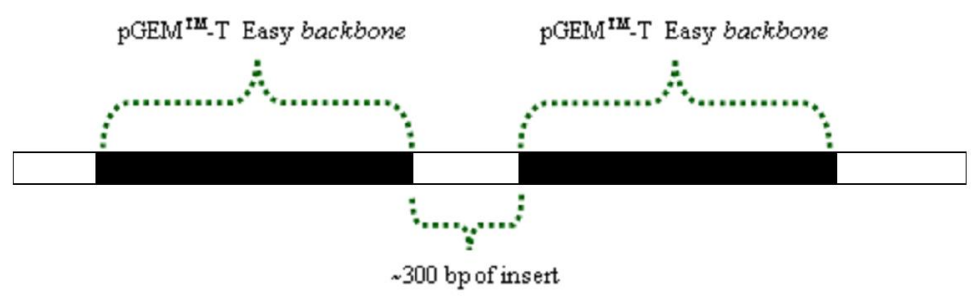

Figure 5. VecScreen ${ }^{\mathrm{TM}}$ Output of Sequencing Consensus Sequence.

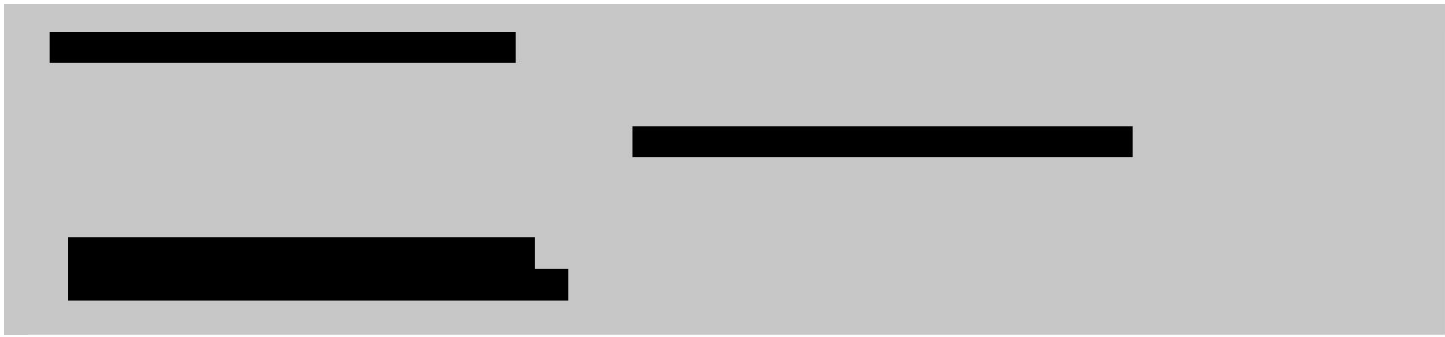

\subsection{Sequencing Analysis}

The plasmid containing insert then was sent for sequencing. It was done using T7 (forward) and SP6 (reverse) primer pairs. Analysis of the result using VecScreen ${ }^{\mathrm{TM}}$ (http://www.ncbi.nlm.nih.gov/VecScreen) showed that only $\sim 300$ bp insert DNA that has been ligated into $\mathrm{PGEM} \mathrm{M}^{\mathrm{TM}}-\mathrm{T}$ Easy vector cloning (Figure 5).

Further analysis of this insert sequence also showed that sequence of primers were found flanked the insert sequence (Figure 6). Thus, the change of insert sequence length from $\sim 1000 \mathrm{bp}$ at initial ligation became $310 \mathrm{bp}$ in the end of cloning must be clarified for several reasons. The first hypothesis be proposed correlated with homolog recombination by host cell. But this hypothesis was failed since $E$. coli $\mathrm{DH} 5 \alpha$ has recA1 in its genotyping. This mutation gene prevented the host to do a homolog recombinant to its contained plasmid (Hanahan et al., 1985). The same pattern of fragment size for every transformation confirmation (always produced $\sim 300$ bp partial fragment) also seemed very rare for homolog recombination activity.

The second hypothesis that been proposed to clarify the change of insert sequence during transformation was correlated to transposable DNA activity. In bacteria, transposon (famous name of a transposable DNA) could jump from chromosome to plasmid and its contrary (Berg et al., 1984). One type of transposons in bacteria known as insertion sequence (IS); it does not contain any additional genes except a gene coding transposase, an enzyme that correlated to transponsition activities. IS was known as $768-1426$ bp in length (McClean, 1997). This hypothesis also being proved since it was found a direct repeat sequence GCCATTGCCATT within the
$310 \mathrm{bp}$ partial fragment (Figure 7). The structure of an IS consist of a transposase encoding region, flanked by an inverted repeat sequence (9-50 bp) and the 5' and 3' short direct repeats (5-11 bp) that generated from the target-site DNA during the insertion of IS (Calos \& Miller, 1980).

The figure below (Figure 8) explained an illustration of hypothesis correlated with transposition activity of an IS (estimated $\sim 700 \mathrm{bp}$ in length) during transformation. At the initial stage of this research (screening of gene), the IS has been estimated still remain linked within the whole screened fragment (we could see the initial size was $\sim 1000 \mathrm{bp}$ ), but during the transformation this IS was moved out from the plasmid and left just 310 bp partial fragment in the end of cloning.

As the next stage of the research, we found that the translation of thus $310 \mathrm{bp}$ of partial fragment have 2 strand of possible ORF, they were frame 1 (52-32) as 67 aa in length and frame $3(32-52)$ as 103 aa (Figure 9). This phenomena was similar with a concept of overlapping gene. The overlapping gene also found in bacteria, since it was abundant in virus (Ellis \& Brown, 2003).

From table 1, we knew that BLASTp result of ORF at frame 1 (52-32) with $\mathrm{nr}$ protein database showed a similarity with Glycogen Debranching Enzyme GlgX [Actinomyces sp. oral taxon 448 str. F0400] with query coverage $=56 \%$, max. identity $=39 \%$, and positive $=$ $57 \%$ (NCBI; (Muzny et al., 2011)). Glycogen debranching enzyme GlgX was include as glycosidehydrolase group $(\mathrm{GH})$ family 13 , as the same family as $\alpha$-Amylase, $\alpha$-Amylase, Glucan 1,4- $\alpha$-glucosidase, etc (http://enzyme.expasy.org/EC/3.2.1.-). In the deep water ocean it was very rare to find polysaccharides 
CATATGCGATTTGAAAGGCGTCACGGCGTACTTGAACACTTCCATGAAGCCCTCAACGGGATCACCCAGGATGGGCCTGCAA TCCACGACCATGCTGTCACCGGTGATCTTATGCCACTCGGCGCTAAGGTCAGTTTGGGATGGCTGAGAGGTAGCCAGAATGA TCATGTGGCAGTGCGGATGCCAGCCATTGCCATTGTTGGTTAGCTCAAGGGTGTAAACCGCTCCCTCTGCCTTGCAAAGCTC TGTCCATGGAGCCCGAGGAACGCCGGAATTGAAGTTGCGGCGATTGTCAGCGTCTATGTGGATCC

Note :

\section{GCCATTGCCATT : Direct repeat sequence}

Figure 7. Direct repeat sequence within the $310 \mathrm{bp}$ insert sequence.

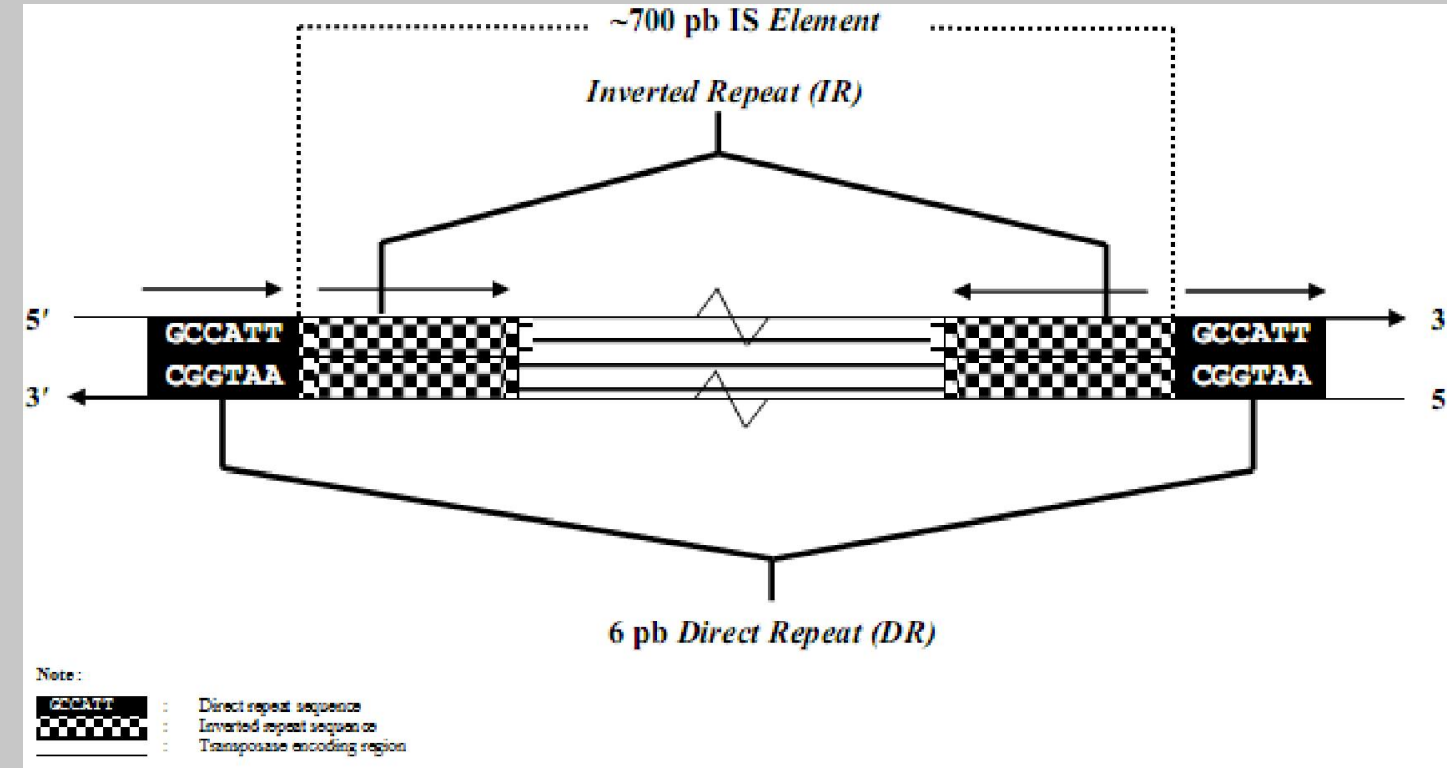

Figure 8. An illustration of Transposons Hypothesis.

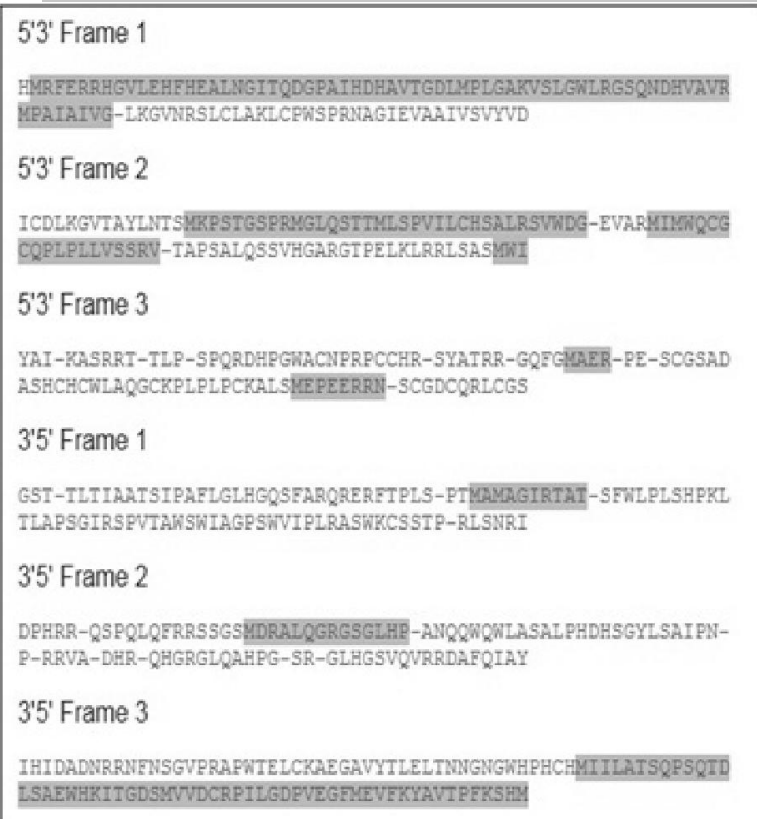

Figure 9. Translation and ORF prediction : Indicate ORF. 
Table 1. BLASTp Result Summary between ORF to Protein "nr" dan "env_nr" Databases

\begin{tabular}{|c|c|c|c|c|c|}
\hline No & $\begin{array}{c}\text { Database } \\
\text { Name }\end{array}$ & BLASTp Result & $\begin{array}{c}\text { Query } \\
\text { Coverage }\end{array}$ & $\begin{array}{c}\text { Max. } \\
\text { Identity }\end{array}$ & Positive \\
\hline \multicolumn{6}{|c|}{ ORF 5'-3' Frame 1 (67 aa) } \\
\hline \multirow[t]{5}{*}{1} & $\mathrm{nr}$ & $\begin{array}{l}\text { putative aminotransferase } \\
\text { [Streptomyces parvulus ] }\end{array}$ & $65 \%$ & $43 \%$ & $54 \%$ \\
\hline & & $\begin{array}{l}\text { aldehyde dehydrogenase } \\
\text { [gamma proteobacterium } \\
\text { HdN1] }\end{array}$ & $80 \%$ & $31 \%$ & $58 \%$ \\
\hline & & $\begin{array}{l}\text { phosphorylase kinase } \\
\text { alphabeta [Halothiobacillus } \\
\text { neapolitanus c2] }\end{array}$ & $77 \%$ & $42 \%$ & $54 \%$ \\
\hline & & $\begin{array}{l}\text { GntR family transcriptional } \\
\text { regulator [Pseudomonas sp. } \\
\text { TJI-51] }\end{array}$ & $83 \%$ & $34 \%$ & $46 \%$ \\
\hline & & $\begin{array}{l}\text { glycogen debranching } \\
\text { enzyme GlgX [Actinomyces } \\
\text { sp. oral taxon } 448 \text { str. F0400] }\end{array}$ & $56 \%$ & $39 \%$ & $57 \%$ \\
\hline 2 & env_nr & $\begin{array}{l}\text { hypothetical protein } \\
\text { GOS_7923894 [marine } \\
\text { metagenome] }\end{array}$ & $55 \%$ & $35 \%$ & $51 \%$ \\
\hline \multicolumn{6}{|c|}{ ORF 3'-5' Frame 3 (103 aa) } \\
\hline \multirow[t]{5}{*}{1} & $\mathrm{nr}$ & $\begin{array}{l}\text { replication protein } \\
\text { [Pseudomonas putida] }\end{array}$ & $88 \%$ & $80 \%$ & $86 \%$ \\
\hline & & $\begin{array}{l}\text { unnamed protein product } \\
\text { [Nitrosomonas } s p .]\end{array}$ & $87 \%$ & $57 \%$ & $71 \%$ \\
\hline & & $\begin{array}{l}\text { RepA [Methylophaga } \\
\text { thalassica] }\end{array}$ & $87 \%$ & $48 \%$ & $61 \%$ \\
\hline & & $\begin{array}{l}\text { hypothetical protein, partial } \\
\text { [Acinetobacter sp. NIPH 236] }\end{array}$ & $86 \%$ & $47 \%$ & $53 \%$ \\
\hline & & $\begin{array}{l}\text { replication protein Rep } \\
\text { [uncultured bacterium] }\end{array}$ & $66 \%$ & $51 \%$ & $64 \%$ \\
\hline \multirow[t]{5}{*}{2} & env_nr & $\begin{array}{l}\text { hypothetical protein } \\
\text { GOS_2869860 [marine } \\
\text { metagenome] }\end{array}$ & $87 \%$ & $46 \%$ & $57 \%$ \\
\hline & & $\begin{array}{l}\text { hypothetical protein } \\
\text { GOS_3844660 [marine } \\
\text { metagenome] }\end{array}$ & $30 \%$ & $55 \%$ & $80 \%$ \\
\hline & & $\begin{array}{l}\text { hypothetical protein } \\
\text { GOS_2712569 [marine } \\
\text { metagenome] }\end{array}$ & $45 \%$ & $40 \%$ & $55 \%$ \\
\hline & & $\begin{array}{l}\text { hypothetical protein } \\
\text { GOS_9602977 [marine } \\
\text { metagenome] }\end{array}$ & $66 \%$ & $28 \%$ & $44 \%$ \\
\hline & & $\begin{array}{l}\text { hypothetical protein } \\
\text { GOS_7442391 [marine } \\
\text { metagenome] }\end{array}$ & $70 \%$ & $30 \%$ & $45 \%$ \\
\hline
\end{tabular}

as substrate, then several starch hydrolyzing-enzymes $\quad=88 \%$, max. identity $=80 \%$, and positive $=86 \%$ might used glycogen as its substrate (Leveque et al., (NCBI; (Holtwick et al., 2001)). Replication protein 2000).

Table 1 also showed that from inverse strand that was frame 3 (32-52), BLASTp result indicated a similarity between query sequence to a replication protein of Pseudomonas putida with query coverage (Rep) was a protein encoding by a plasmid and was known involved in plasmid replication process. Rep encoding gene mostly found in plasmids that used theta mechanism as its replication mechanism, even though it was also found in any plasmids that used 


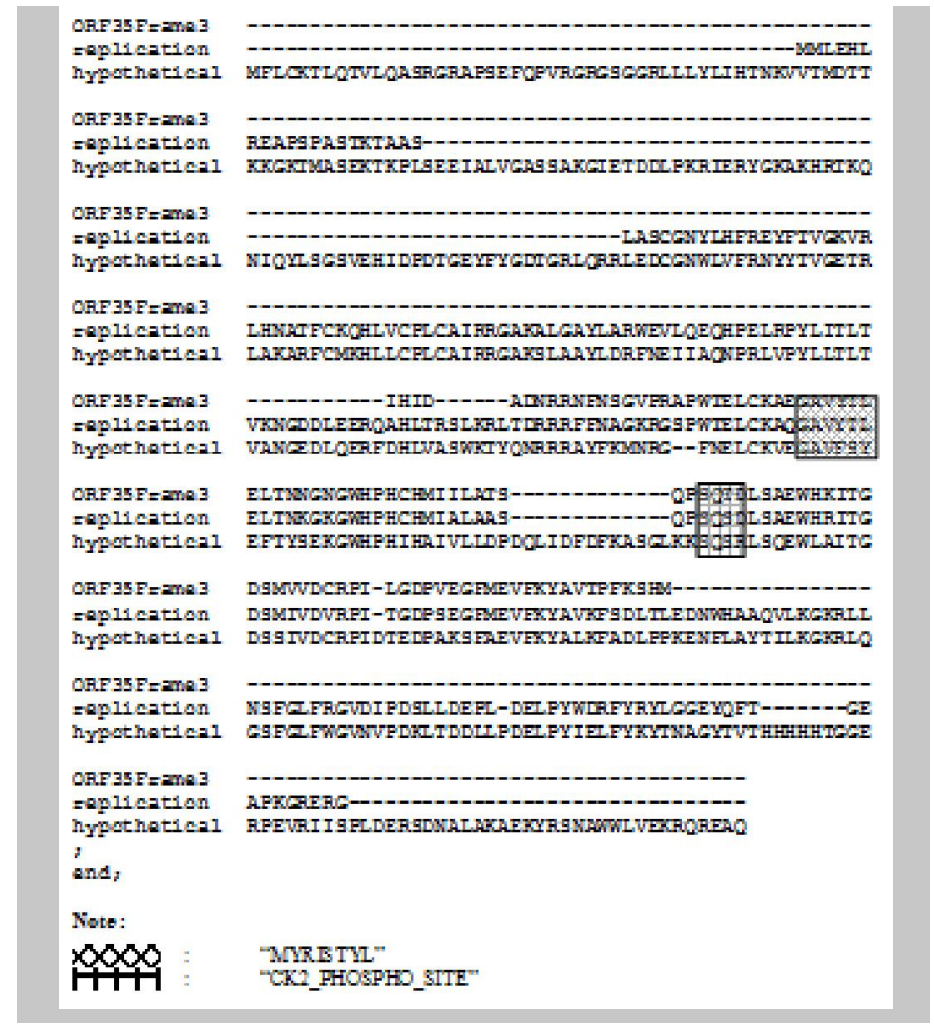

Figure 10. Multiple alignment result of Sekuen ORF frame 3 (32-52), Replication Protein [Pseudomonas putida], and Hypothetical Protein_GOS2869860.

both strand displacement replication and rolling-circle replication during replication process (Solar $\mathrm{G}$ et al., 1998).

When used "env_nr", BLASTp result showed that the ORF at frame $3(32-52)$ also similar with hypothetical protein GOS-_2869860 (Query Coverage: 87\%; Max. Identity: 46\%, Positive: 57\%). Hypothetical protein_GOS databases were collected during expedition of "The Sorcerer II Global Ocean Sampling (GOS) Expedition : Northwest Atlantic through Eastern Tropical Pacific" on 2003 and 2004 (Yooseph et al., 2007). This expedition was sponsored by The J. Craig Venter Institute in order to explore genome databases form marine bioresources (Rusch et al., 2007).

\subsection{Conserved Domain, Active Site and Protein Motif Characterization}

Further characterization was done for ORF at frame $3(32-52)$, since it has the highest value of BLASTp result. In this stage, the ORF also being compared with replication protein sequence from Pseudomonas putida and hypothetical protein GOS_2869860 sequence from marine metagenomic research.

Conserved domain analysis using Conserved Domian Database (cdd ${ }^{\circledR}$ ) (http://www.ncbi.nlm.nih.gov/ Structure/cdd/cdd.shtml) showed that
Rep_1_superfamily" domain was found as conserved domain of this ORF, this domain also found in both replication protein sequence from Pseudomonas putida and hypothetical protein GOS_2869860 sequence from marine metagenomic. Rep_1_superfamily" domain indicated region of replication protein encoding, and known that it was involved in plasmid replication process (Marsin et al., 1998). By using EXPASY Prosite ${ }^{\mathrm{TM}}$ (http:// prosite.expasy.org/), active sites of ORF sequence were identified. But the result showed that there were no active site found in the ORF sequence, also in both replication protein sequence from Pseudomonas putida and hypothetical protein GOS_2869860 sequence from marine metagenomic. Protein motifs of each sequence were identified using MotifScan ${ }^{\mathrm{TM}}$ (http://myhits.isb-sib.ch/cgi-bin/motif scan). The result showed there were 3 protein motifs found in the ORF sequence, they were "MYRISTYL" was found at 28-33 [GAVYTL], "CK2_PHOSPHO_SITE" was found at 57-60 [SQTD], and "MICROBODIES_CTER" [SHM] was found at 101-103. The result also showed that the ORF has similarity with replication protein sequence from Pseudomonas putida and hypothetical protein GOS_2869860 sequence from marine metagenomic in the motifs of "MYRISTYL" and "CK2_PHOSPHOP_SITE" (Figure 10). 


\section{Conclusion}

The $\alpha$-amylase encoding gene could not isolated from metagenomic DNA derived from deep-sea water and sediment in this research. But, a fragment as $\sim 1000$ bp in length was successfully isolated through touchdown PCR method. The presence of a transposon in this DNA fragment is proposed as a hypothesis for losing $~ 700$ bp leaving just 310 bp cloned sequence. This hypothesis was supported by the presence of a direct repeat sequence GCCATTGCCATT within the 310 bp partial fragment that indicated a transposon trait. Analysis of sequencing result showed a highest similarity between this 310 bp partial fragment with a replication protein (Rep) encoded gene from Pseudomonas putida (Query Coverage: $88 \%$; Max. Identity: $80 \%$, Positive: $86 \%$ ) and this protein is known to be involved in plasmid replication.

\section{Acknowledgement}

This research was supported by grant from Hibah Riset KK SITH-ITB 2010/2011.

\section{Reference}

Aziz, R. K. M., Breitbart, \& Edwards, R. A. (2010). Transposases are the most abundant, most ubiquitous genes in nature. Nucleic Acids Research, 38(13), 4207-4217.

Berg, D. E., Berg, C. M., \& Sasakawa C. (1984). Bacterial Transposon Tn5: Evolutionary Inferences. Mol. Biol. Evol., 1(5), 411-422.

Calos, M. P. \& Miller, J. H. (1980). Cell. p. 1280.

Collins, T., Meuwis, M. A., Stals, I., Claeyssens, M., Feller, G., \& Gerday, C. (2002). A novel family 8 xylanase, functional \& physicochemical characterization. J. Biol. Chem., 277, 35133-35139.

Dean, F. B., Hosono, S., Fang, L., Wu, X., Faruqi, A.F., Bray-Ward, P., Sun, Z., Zong, Q., Du, Y., Du, J., Driscoll, M., Song, W., Kingsmore, S. F., \& Egholm, M. (2002). Comprehensive Human Genome Amplification using Multiple Displacement Amplification. Proceedings of The National Academy of Sciences. USA 99: 52615266.

Ferrer, M., Golyshina, O. V., Chernikova, T. N., Khachane, A. N., Martins Dos Santos, V. A., Yakimov, M.M., Timmis, K.N., \& Golyshin, P.N. (2005). Microbial enzymes mined from the Urania deep-sea hypersaline anoxic basin. Chem. Biol., 12, 895-904.

Hanahan, D. (1985). In DNA Cloning: A Practical Approach (Glover, D.M., ed.)( p. 109), Vol. 1, McLean, Virginia: IRL Press.

Handelsman, J., James, M., Tiedje, Cohen. L. A., Michael Ashburner, ... Ann, H. R (p. 24). (2007). Understanding Our Microbial Planet: The New Science of Metagenomics. The National Academy of Science.

Hobel, C. F., Hreggvidsson, G. O., Marteinsson, V. T., Bahrani-Mougeot, F., Einarsson, J. M., \& Kristjansson, J.K. (2005). Cloning, expression, \& characterization of a highly thermostable family 18 chitinase from
Rhodothermus marinus. Extremophiles, 9, 53-64.

Jeon, J. H., Kim, J. T., Kim, Y. J., Kim, H. K., Lee, H. S., Kang, S. G., Kim, S. J., \& Lee, J.H. (2009). Cloning \& characterization of a new cold-active lipase from a deep-sea sediment metagenome. Appl. Microbiol. Biotechnol., 81, 865-874.

Lane, D. J., Pace Bernadettl, Olsen G. J., Stahl, D. A. Sogin, M. L., \& Pace, N. R. (1985). Rapid determination of $16 S$ ribosomal RNA sequences for phylogenetic analyses. Proc. Natl. Acad. Sci., 82, 6955-6959.

Lasken R. S. \& Egholm, M. (2003). Whole-genome ampliûcation: abundant supplies of DNA from precious samples or clinical specimens. Trends Biotechnol., 21, 531.

Mathur, E. J., Toledo, G., Green, B. D., Podar, M., Richardson, T. H., Kulwiec, M., \& Chang, H. W. (2006). A biodiversity-based approach to development of performance enzymes. Ind. Biotechnol., 1, 283-287,

McClean, P. (1997). Bacterial Transposable Element. Review of Transposable Genetics Element. 2, 11-13.

Paez, J. G., Lin, M., Beroukhim, R. Lee, J. C, Zhao, X., Richter, D. J., Gabriel, S., Herman, P., Sasaki, H., Altshuler, D., Li, C., Meyerson, M., \& Sellers, W. R. (2004). Genome coverage and sequence fidelity of the phi29 polymerase-based multiple strand displacement whole genome ampliûcation. Nucleic Acids Research, 32, 71.

Park, H. J., Jeon, J. H., Kang, S. G., Lee, J. H., Lee, S. A.; \& Kim, H. K. (2007). Functional expression and refolding of new alkaline esterase, EM2L8 from deepsea sediment metagenome. Protein Expr. Purif., 52, 340-347.

Rahmani, Nanik, Yopi, Andriani, A., \& Prima, A. (2011). Production and Characterization of Amylase Enzyme from Marine Bacteria. Proceedings of the $2^{\text {nd }}$ International Seminar on Chemistry. pp. 255-259.

Roychoudhury, A., Basu, S., \& Dibyendu, N. S. (2009). Analysis of Comparative Efficiencies of Different Transformation Methods of E. coli using Two Common Plasmid Vectors. Indian Journal of Biochemistry and Biophysics, 46, 395-400.

Schloss, P. D. \& Handelsman, J. (2003). Biotechnoligical prospects from metagenomics. Curr. Opin. Biotechnol., 14, 303-310.

Sharma, R. (2005). Unculturable' bacterial diversity. An untapped resource. Curr. Sci., 89, 72-77.

Steele HL and Streit WR. (2005). Metagenomics: advances in ecology and biotechnology. FEMS Microbiol. Lett., 247, 105-111.

Tu, Z., He, G., Li, K. X., Chen, M. J., Chang, J., Chen, L., Yao, Q., Liu, D. P., Ye, H., Shi, J., and Wu, X. (2005). An Improved System for Competent Cell Preparation \& High Efficiency Plasmid Transformation using Different Escherchia coli Strains. Electronic Journal of Biotechnology, 8(1), 113-120.

Vakhlu, J., Sudan, A. K., \& Johri, B. N. (2008). Metagenomic : Future of microbial gene mining. Indian J. Microbiol., 48, 202-215.

Xu, M., Xiao, X., \& Wang, F. (2008). Isolation \& characterization of alkane hydroxylases from a metagenomic library of Pacific deep-sea sediment. Extremophiles, 12, 255-262.

Zeng, R., Zhang, R., Zhao, J., \& Lin, N. (2003). Coldactive serine alkaline protease from the psychrophilic bacterium Pseudomonas strain DY-A: enzyme purification \& characterization. Extremophiles, 7, 335337. 